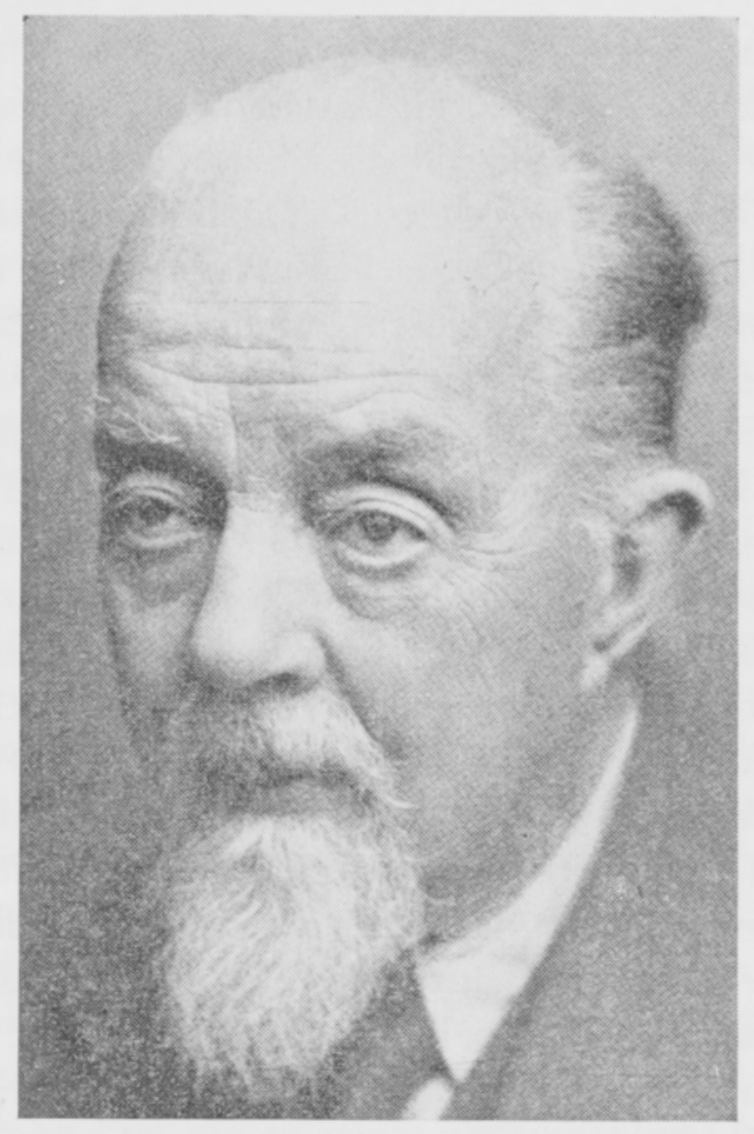

\title{
EILHARD ALFRED MITSCHERLICH
}

*29. 8. $1874-+$ 3. 2. 1956

Suomen maataloustieteellisen seuran kunniajäsen, professori EILHARD ALFRED MitscherLich kuoli 3. 2. 1956 Berliinissä. Hän kuului tunnettuun tieteenharjoittajain sukuun. Hänen isänsä oli kirurgian professori Gustav Alfred Mitscherlich ja hänen isoisänsä tunnettu kemisti Eilhard Mitscherlich. Viimeksi mainitusta polveutuu kuusitoista tunnettua tiedemiestä, heistä kaksi nyt kuolleen E. A. Mitscherlichin poikaa. Äitinsä puolelta hän kuului sukuun, joka Schlesiassa omisti suuria sukutiloja ja joilla hänellä oli tilaisuus soveltaa tutkimustyönsä tuloksia käytäntöön.

Opiskeltuaan Kielin ja Berliinin yliopistoissa kemiaa, fysiikkaa ja kasvitiedettä hän väitteli tohtoriksi ensiksi mainitussa yliopistossa maan kostumislämpöä koskevalla tutkimuksellaan. Tällä ja seuraavalla maan hygroskooppisuutta selvittävällä tutkimuksellaan, jotka molemmat olivat vaatineet paljon työtä ja erikoista tarkkuutta, hän tuli tunnetuksi taitavana tieteenharjoittajana, josta on osoituksena, että hän viimeksi mainitulla tutkimuksellaan sai Liebigin palkinnon.

Mitscherlichin maan fysikaalisia ominaisuuksia koskevat harrastukset saivat myöhemmin väistyä, sillä maan kemialliset ominaisuudet ja erityisesti kasvien ravinnon saantiin liittyvät ilmiöt tulivat hänen tutkimuksensa keskeisiksi kohteiksi. Näihin töihin hänelle tarjoutui erinomainen tilaisuus kun hänestä v. 1906 
tuli Königsbergin yliopiston kasvinviljelystieteen professori. Siellä hän on suorittanut varsinaisen elämäntyönsä, sillä huolimatta monista houkuttelevista tarjouksista hän pysyi uskollisesti Königsbergin yliopistossa emeritusikäänsä saakka. Mainittu yliopisto käytti hyväkseen myös hänen hallinnollisia taitojaan, jotka erityisesti vaikeina murrosaikoina pääsivät oikeuksiinsa. Hän oli useita kertoja sikäläisen filosofisen tiedekunnan dekaanina ja myös yliopiston rehtorina. Mutta ennen kaikkea hän tuli siellä tunnetuksi kasvien ravitsemuksen tutkijana ja kasvifysiologina. Hänen laitokseensa saapui opiskelijoita kaikista Saksan yliopistoista sekä lisäksi runsaasti ulkomailta.

Kasvien ravitsemusta ja maan lannoituksen tarvetta Mitscherlich on koettanut selvittää sekä kemiallisia menetelmiä käyttäen että varsinkin astiakokeiden avulla. Edellisessä tarkoituksessa hän otti käytäntöön hiilihappomenetelmän. Sen soveliaisuutta selvitellessään hän tutki ravinteiden liukenevuutta käytettäessä erilaisia konsentraatioita, eri pitkiä uuttoaikoja sekä erilaisia lämpötiloja. Kemiallisten maan lannoituksentarpeen määrittämismenetelmien kohdalla on erityisesti syytä korostaa Mitscherlichin osuutta mainittua tarkoitusta varten kehitettyjen erilaisten menetelmien vertailevien tutkimusten aikaansaamiseksi. Tätä tarkoitusta varten perustettiin eri puolille Keski- ja Pohjois-Eurooppaa kenttäkokeita ja niistä lähetettiin suuret maanäytteet Königsbergiin. Mitscherlichin laitoksessa niistä määritettiin lannoituksentarve astiakokeiden ja lukuisten erilaisten kemiallisten menetelmien avulla. Lisäksi hienoksi jauhettuja näytteitä lähetettiin eri laboratorioihin niissä kehitetyillä menetelmillä tutkittaviksi. Mm. Suomi osallistui tähän työhön. Tuloksena voitiin todeta, että silloisilla kemiallisilla menetelmillä vain harvoin saatiin yhtäpitäviä tuloksia, eikä niistä mikään osoittautunut yleispäteväksi. Kehitys on myöhemmin kulkenutkin siihen suuntaan, että maan lannoituksen tarpeen määrittäminen tafahtuu eri puolilla maailmaa kunkin seudun luonnonsuhteiden ja kasvituotannon mukaisia menetelmiä käyttäen. Mitscherlichin kehittämä astiakoemenetelmä on kuitenkin yleisesti käytännössä jokseenkin kaikkialla. Hänen toimestaan suoritettiin sitä käyttäen maan lannoituksen tarpeen määrittämisiä Itä-Preussissa sangen laajassa mittakaavassa. Niinpä 1930-luvun lopulla tarkoitukseen oli käytettävissä neljä suurta koeasemaa ja niissä yhteensä 24000 astiaa. Mitscherlichille lankeaa erityinen ansio tämän menetelmän kehittämisestä.

Erittäin laajalti on Mitscherlichin nimi tullut tunnetuksi niiden tutkimusten johdosta, jotka koskevat kasvutekijöitä ja niiden lainalaisuutta. Viimeksi mainitussa suhteessa hän on erityisesti korostanut sitä, että kasvien kasvu edellyttää kaikkien kasvutekijöiden läsnäoloa. Samoin hän on kiinnittänyt huomiota siihen, että minimissä olevan kasvutekijän ohella muidenkin kasvutekijöiden muutokset aiheuttavat sadon suuruuden vaihteluja. Tämän takia sadon suurenemista ei voida esittää suoralla viivalla kuten Liebigin minimilaki edellyttää, vaan käyrällä. Mitscherlichin kasvutekijäin vaikutuslaki esitetään matemaattisesti seuraavasti:

$$
\frac{d y}{d x}=(A-y) \cdot c
$$


Sen mukaan sadon lisäys (dy) kasvutekijän kohotessa (dx:llä) on suoraan verrannollinen kysymyksessä olevissa olosuhteissa suurimman sadon (A) ja kasvutekijän arvolla $\mathrm{x}$ saavutetun sadon (y) väliseen erotukseen. Kasvutekijän lisäämisestä johtuva sadon paraneminen on sitä suurempi, mitä enemmän sato on korkeinta satoa pienempi. Mitscherlichin kasvutekijäin vaikutuslaki on voimassa vain silloin, kun sadot liikkuvat optimin alapuolella. Sikäli kun kasvutekijää lisätään niin paljon, että se rupeaa vaikuttamaan satoa alentavasti, hän puhuu kasvua vahingoittavista tekijöistä ja esittää myös tätä tapausta varten matemaattisen kaavan sekä joukon tyypillisiä esimerkkejä.

Mitscherlichin esittämä kasvutekijäin vaikutuskerroin (c) on aiheuttanut paljon mielipiteiden vaihtoa. Hänen mukaansa tämä arvo on eri kasvutekijöille vakio, ja siitä johtuen kasvutekijöiden vaikutuskäyrät ovat erilaisia. Pääravinteiden vaikutuskertoimet ovat seuraavat: $\mathrm{N}=0.20, \mathrm{~K}_{2} \mathrm{O}=0.40, \mathrm{P}_{2} \mathrm{O}_{5}=0.60$. Magnesiumin vaikutuskerroin on 2.0 ja rikin 15.0 . Kun eräät tutkijat ovat epäilleet sitä, että vaikutuskertoimet olisivat vakioita, on Mitscherlich laajoilla tutkimuksillaan osoittanut teoriansa oikeaksi edellyttäen, että kaikkia kasvinravintoaineita on samanaikaisesti runsaasti saatavilla eli toisin sanoen kasvintuotannossa pyritään kunnollisiin ja mieluimmin optimisatoihin. Hänen johtamassaan Paulinenauessa lähellä Berliiniä sijaitsevassa tutkimuslaitoksessa on kyllä voitu osoittaa, että jos esim. typpeä annetaan suhteettoman runsaasti muihin ravinteisiin nähden, sen vaikutuskerroin poikkeaa edellä esitetystä.

Mitscherlichin erinomaisen laajaa tieteellistä julkaisutoimintaa ei tässä yhteydessä voida lähemmin ryhtyä selostamaan. Todettakoon vain että hänen töitään on löydettävissä mitä moninaisimmissa julkaisusarjoissa ja kongressikertomuksissa. Hänen jo v. 1905 julkaisemansa maaperäopin oppikirja (Bodenkunde für Landwirte, Forstwirte und Gärtner) on jatkuvasti ollut käytännössä ja tänä vuonna siitä on ilmestynyt 8. painos. Se perustuu ennenkaikkea Mitscherlichin omiin tutkimuksiin. Siinä on lisäksi paljon aineistoa viime vuosisadan tutkimuksista, erityisesti Wollnyn maan fysikaalisia ominaisuuksia koskevia. Tälle maaperäopille samoinkuin kaikille Mitscherlichin tutkimuksille on luonteenomaista runsas matemaattinen esitys. Hän lieneekin ensimmäinen, joka on ryhtynyt käyttämään tilastomatemaattista menettelyä koetulosten esittelyssä. Tämän johdosta hän sai aikoinaan paljon vastustusta, mutta myöhemmin tämä tapa on otettu yleisesti käytäntöön. Mitscherlichin maaperäopin oppikirja eroaa sangen oleellisesti muista vastaavista sen johdosta, että siinä ei kiinnitetä maan mineralogisiin ja geologisiin ominaisuuksiin lainkaan huomiota. Tämä johtuu siitä, että hän katsoo muokkaus-, lannoitus- ja muiden hoitotoimenpiteiden vaikuttavan niin voimakkaasti peltomaan ominaisuuksiin, että maan alkuperäiset ominaisuudet jäävät niiden takia kokonaan varjoon. Hänen mielestään on samantekevää, mitenkä ja mistä mineraaleista ja kivilajeista peltomaa on syntynyt.

Saavutettuaan v. 1941 emeritusiän Mitscherlich vetäytyi sukutilalleen Schlesiaan viettämään vanhuuttaan. Sodan johdosta hän kuitenkin menetti kaiken omaisuutensa ja parahiksi onnistui säilymään hengissä. Hän kävi kuitenkin lannistumatta työhön taas käsiksi. Oltuaan aluksi radion palveluksessa hän tuli maan- 
viljelystekniikan professoriksi Humboldtin yliopistoon Itä-Berliiniin. Sittemmin Saksan tiedeakatemia järjesti hänelle mahdollisuuden jatkaa kasvinviljelyä koskevia tutkimuksiaan lähellä Berliiniä sijaitsevalla Paulinenauen koetilalla. Tarkoitusta varten sinne rakennettiin tarpeelliset laboratoriotilat, astiakoehallit ja kunnostettiin koekenttiä. Hänellä oli siellä 45 apulaista ja hän työskenteli virkeästi viime vuoden syksyyn saakka.

Kansainvälisesti tunnettuna tutkijana professori Mitscherlich on pitkän elämänsä aikana saanut osakseen monta kunnianosoitusta. Eräs häntä varmaankin eniten ilahduttanut ja samalla laajat työmahdollisuudet avannut oli Preussin maanviljelijöiden perustama Mitscherlich-yhdistys, joka teki hänelle mahdolliseksi antautua taloudellisista huolista vapaana tutkimustyöhän. Ja onnistuneesta työstään maatalouden hyväksi hänet on kutsuttu Saksan maatalousseurojen kunniajäseneksi. Königsbergin, Kielin ja Berliinin yliopistot ovat vihkineet hänet kunniatohtorikseen. Lisäksi monet ulkomaalaiset seurat ja tiedeakatemiat ovat kutsuneet hänet jäsenekseen. Niinpä Mitscherlich oli mm. Suomen Maataloustieteellisen Seuran kunniajäsen sekä Suomalaisen Tiedeakatemian ulkomaalainen jäsen. Samoin Ruotsin maatalousakatemia oli kutsunut hänet jäsenekseen. Vuodesta 1935 lähtien Mitscherlich oli myös Kansainvälisen Maantutkimusseuran kunniajäsen.

Professori Mitscherlich oli tieteenharjoittaja, joka on jatkuvasti työskennellyt kiinteästi omalla alallaan ja saavuttanut siinä erinomaisia tuloksia. Ne joilla on ollut tilaisuus tutustua häneen, muistavat aina mielihyvin sen kodikkaan jà vaatimattoman tavan, jolla tämä kuuluisa tutkija on ottanut heidät laitoksessaan vastaan, perehdyttänyt heidät tutkimusmenetelmien yksityiskohtiin ja ollut valmis keskustelemaan kulloinkin ajankohtaisista ammattikysymyksistä. Niinpä minun miellyttävimpiin ulkomaan muistoihin kuuluvat ne päivät, jotka olen viettänyt Mitscherlichin laitoksessa Königsbergissä.

Myöskin Suomen maatalous ja etenkin maataloustieteellinen tutkimus on saanut paljon vaikutteita ja hyötynyt Mitscherlichin työstä. Samalla kun taitavan tutkijan kuolema aiheuttaa syvän kaipauksen tunteen muistelemme häntä ja hänen työtään erittäin suurella kiitollisuudella ja lämmöllä.

Erkki Kivinen 